\title{
Incidence and management of intercostal patch aneurysms after repair of thoracoabdominal aortic aneurysms
}

\author{
Alexander Kulik, MD, MPH, Brent T. Allen, MD, and Nicholas T. Kouchoukos, MD
}

\begin{abstract}
Objective: The reimplantation of intercostal arteries during the repair of descending thoracic aortic or thoracoabdominal aortic aneurysms preserves spinal cord perfusion and might reduce the risk of spinal cord ischemic injury. However, the retained cuff of native aortic tissue around the intercostal vessels might become aneurysmal. We reviewed our experience with patients who had intercostal patch aneurysms after descending thoracic aortic and thoracoabdominal aortic aneurysm repair.
\end{abstract}

\begin{abstract}
Methods: From January 1986 to July 2008, 38 patients with descending thoracic aortic aneurysms and 117 patients with thoracoabdominal aortic aneurysms underwent surgical repair with cardiopulmonary bypass, hypothermic circulatory arrest, and intercostal artery reimplantation as a Carrel patch. Eleven (7.1\%) of these 155 patients ( 2 with descending thoracic aortic aneurysms and 9 with thoracoabdominal aortic aneurysms) developed intercostal patch aneurysms that required surgical treatment. Using either a repeat open operation $(n=8)$ or endovascular stent graft placement $(\mathrm{n}=3)$, we repaired 11 intercostal patch aneurysms a mean of 5.3 years after the initial repair (range, 0.1-13.7 years). Five of the 11 patients had Marfan syndrome.
\end{abstract}

Results: There were no in-hospital deaths or reoperations for bleeding, strokes, or spinal cord ischemic injury, and no patient had renal failure requiring dialysis. Two patients had late aortic graft infections. During the follow-up interval that extended to 7.5 years, there were 6 late deaths from 31 to 90 months postoperatively.

Conclusions: Intercostal patch aneurysms are a complication of the sparing of intercostal arteries during thoracic aneurysm repair. They can be safely repaired with either open or endovascular techniques.

The reimplantation of intercostal and lumbar arteries below the T7-T8 level might reduce the risk of spinal cord ischemic injury (SCII) during repair of descending thoracic aortic aneurysms (DTAAs) and thoracoabdominal aortic aneurysms (TAAAs). ${ }^{1}$ This can be accomplished with the Crawford inclusion technique, creating a side-to-side anastomosis between the prosthetic graft and the aorta surrounding the intercostal vessels, ${ }^{2}$ or with a Carrel patch, performing an end-to-side anastomosis between the prosthetic graft and a full-thickness aortic patch containing the intercostal arteries.

Although potentially reducing the risk of SCII, retaining native aorta around the reimplanted vessels might place the patient at risk of subsequent aneurysmal expansion of the aortic patch and rupture. ${ }^{3,4}$ A number of patients undergoing DTAA and TAAA repair have chronically dissected and therefore weakened aortic tissue..$^{5-8}$ Many of these patients also have connective tissue disorders, such as Marfan syndrome. Thus there is the potential for anastomotic

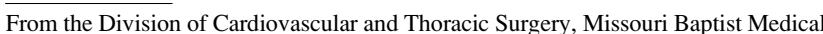
Center, St Louis, Mo.

Received for publication Oct 21, 2008; revisions received Dec 12, 2008; accepted for publication Jan 4, 2009; available ahead of print March 9, 2009.

Address for reprints: Nicholas T. Kouchoukos, MD, Cardiac, Thoracic and Vascular Surgery, 3009 N Ballas Road, Suite 360C, St Louis, MO 63131 (E-mail: ntkouch@aol.com).

J Thorac Cardiovasc Surg 2009;138:352-8

$0022-5223 / \$ 36.00$

Copyright (c) 2009 by The American Association for Thoracic Surgery doi:10.1016/j.jtcvs.2009.01.005 dehiscence or continued dilatation of fragile and diseased native aortic wall surrounding the intercostal vessels.

Previous studies have suggested that the risk of visceral artery patch aneurysms after TAAA repair with the Crawford inclusion technique or a Carrel patch is between $4 \%$ and $8 \%{ }^{3,9,10}$ To our knowledge, no study has documented the risk of intercostal patch aneurysm or evaluated the options for treatment of this complication. We reviewed our experience with intercostal artery reimplantation using the Carrel patch technique to determine the incidence of intercostal patch aneurysms and the optimal method of management.

\section{MATERIALS AND METHODS}

\section{Incidence of Intercostal Patch Aneurysms}

From January 1986 to July 2008, a total of 171 patients with DTAAs and 199 patients with TAAAs underwent surgical repair with cardiopulmonary bypass, hypothermic circulatory arrest, and graft replacement of the descending thoracic or thoracoabdominal aortas. Of this group, 38 patients with DTAAs and 117 with TAAAs underwent reimplantation of patent intercostal arteries with a Carrel patch as small as technically feasible, with the size dictated by the number of reimplanted vessels. In general, large patent intercostal arteries below the T5-T6 level were reimplanted, particularly in patients with more extensive aortic disease (ie, extent II TAAA repair and previous abdominal aortic aneurysm repair) and in patients with presumably less extensive collateral circulation to the spinal cord (ie, patients with aortic dissection and many patent intercostal arteries). No eversion endarterectomy was performed on any of the intercostal vessels in the patients in this series. For the purposes of this study, an intercostal patch aneurysm was defined as a pseudoaneurysm along the intercostal patch anastomotic suture line or a dilatation of the native aorta accompanying the intercostal vessels leading to an aortic diameter of greater than $5.5 \mathrm{~cm}$. Among the 


\section{Abbreviations and Acronyms}

$\mathrm{CT}=$ computed tomographic

DTAA $=$ descending thoracic aortic aneurysm

SCII = spinal cord ischemic injury

$\mathrm{TAAA}=$ thoracoabdominal aortic aneurysm

155 patients who had reimplantation of patent intercostal arteries, $5(22.7 \%)$ of 22 patients with Marfan syndrome developed intercostal patch aneurysms compared with $6(4.5 \%)$ of 133 patients without Marfan syndrome $(P<$ $.01)$.

A total of $11(7.1 \%)$ patients who initially underwent DTAA/TAAA surgery at our center developed intercostal patch aneurysms, including 2 $(5.3 \%)$ patients with DTAAs and $9(7.7 \%)$ patients with TAAAs. One of the patients with a DTAA underwent intercostal patch aneurysm repair at another institution. We repaired the intercostal patch aneurysms of the other 10 patients, as well as an aneurysm of one additional patient who underwent initial TAAA repair at another institution. The 11 patients in whom we performed repairs are the focus of this study. The study was reviewed by the Institutional Review Board of the Missouri Baptist Medical Center and was exempted from Board approval.

\section{Patient Characteristics}

The clinical characteristics of the 11 patients are shown in Table 1 . The mean age at reoperation was 54.2 years (range, 39-76 years). There were 5 men and 6 women. Five patients had undergone repair of a Crawford extent I TAAA, 5 patients had Crawford extent II TAAA repair, and 1 patient had repair of a DTAA (proximal 2/3). The mean interval between the initial DTAA/TAAA repair and the patch aneurysm repair was 5.3 years (range, $0.1-13.7$ years)

The indications for operation in 10 patients were a thoracic aortic size of greater than $5.5 \mathrm{~cm}$ (mean diameter, $7.1 \mathrm{~cm}$ ) or serial computed tomographic (CT) evidence of rapid expansion (Figure 1). Four patients had chest or back pain. One patient (patient 2) required emergency surgical intervention, having presented with back pain, hemoptysis, and a left hemothorax 1 month after repair of Crawford extent I TAAA. This patient had a contained rupture of a false aneurysm along the intercostal patch suture line. Patients 1 and 5 had more extensive aneurysmal disease that required surgical repair in addition to the intercostal patch aneurysm (patient 1: false aneurysms at the proximal and distal suture lines and an abdominal aortic aneurysm; patient 5: visceral patch aneurysm). In total, 2 patients had pseudoaneurysms along the intercostal patch suture line (patients 1 and 2), whereas all other patients had true aneurysms of the aortic patch.

Before 2006, all patients presenting with intercostal patch aneurysms were managed with redo thoracotomy, resection of the intercostal patch and the segment of graft to which it was attached, and interposition of a new segment of graft. Since 2006, patients have been considered for endovascular stent graft repair as an alternative to open operation. Patients 7,10 , and 11 were not candidates for endovascular stent graft repair because of insufficient distal landing zones between the aneurysm and the origin of the celiac artery (Figure 2).

\section{Open Operation}

Technique. Our technique for open operation with cardiopulmonary bypass and hypothermic circulatory arrest has been previously reported. ${ }^{5,11}$ Lumbar spinal drains were inserted in the 4 most recent open operations (patients 5, 7, 10, and 11) for cerebrospinal fluid drainage and additional protection of the spinal cord. ${ }^{12}$ Patients were positioned in a right lateral decubitus position with the hips turned to the left at a $45^{\circ}$ angle. A standard posterolateral thoracotomy incision was made either through the fifth or sixth intercos- tal space. Simultaneously, the left common femoral artery and vein were isolated through an oblique incision in the skin crease of the groin. After heparin administration, a long cannula $(28 \mathrm{~F}-34 \mathrm{~F})$ was inserted through the left common femoral vein, and the tip was positioned in the right atrium under transesophageal echocardiographic guidance. The femoral artery was cannulated with a $20 \mathrm{~F}$ or $22 \mathrm{~F}$ cannula. Cardiopulmonary bypass was established, and cooling was initiated with a target temperature of $15^{\circ} \mathrm{C}$ to $17^{\circ} \mathrm{C}$. Circulatory arrest was then established for a single period.

During the interval of circulatory arrest, the segment of aortic graft containing the patch aneurysm was incised. Thrombus within the aneurysm was removed, and the anatomy was carefully examined. The graft was transected above the level at which the intercostal patch aneurysm originated. A new collagen-impregnated woven polyester aortic graft $(26-32 \mathrm{~mm})$ containing a 10-mm side arm (Hemashield; Meadox Medicals, Inc, Oakland, NJ) was sutured end-to-end to the remaining proximal segment of graft with a continuous 3-0 or 4-0 polypropylene suture buttressed with a strip of felt. As this suture line was completed, cold blood $\left(10^{\circ} \mathrm{C}-12^{\circ} \mathrm{C}\right)$ from the pump oxygenator was infused retrogradely into the venous cannula to assist in the evacuation of air and debris from the upper circulation and from the graft (flow rate, $800 \mathrm{~mL} / \mathrm{min}$; maximum central venous pressure, $20 \mathrm{~mm} \mathrm{Hg}$ ). The side arm of the new graft was attached to a second arterial line from the pump oxygenator. After evacuation of air, a clamp was placed on the new graft just distal to the side arm, and flow to the upper body was re-established at a rate of 15 to $20 \mathrm{~mL} / \mathrm{kg}$ and a temperature of $20^{\circ} \mathrm{C}$ to $22^{\circ} \mathrm{C}$.

The graft segment containing the patch aneurysm was transected below the aneurysm. The distal anastomosis of the interposition graft to the remaining graft or to the distal aorta was performed with a continuous 3-0 or 4-0 polypropylene suture buttressed with a strip of felt. As the distal suture line was being completed, arterial perfusion was re-established through the femoral artery to evacuate air. Additional air was evacuated from the grafts through multiple puncture sites created with an 18-gauge needle. Flow from the femoral arterial line was subsequently discontinued, full antegrade flow was established from the second arterial line, and rewarming commenced. Cardiopulmonary bypass was discontinued when the bladder temperature reached $35^{\circ} \mathrm{C}$.

One patient (patient 2) had a left hemothorax 1 month after initial repair of extent I TAAA. She had a contained rupture of a false aneurysm along the intercostal patch suture line. The left hemothorax was evacuated, and the suture line of the intercostal patch was repaired with pledgeted sutures by using hypothermic cardiopulmonary bypass.

Intercostal artery management. A decision whether to reimplant or ligate patent intercostal arteries within the patch aneurysm was made after completion of the aortic interposition graft. Large intercostal arteries below $\mathrm{T} 7$ were judged to be important for spinal perfusion, particularly after previous extent II TAAA repair. They were reimplanted with either a new intercostal Carrel patch (patient 1) or a side branch graft to the aortic graft (patients 4 and 5). Patients 7 and 10 had markedly dilated and thin aortic tissue adjacent to small patent intercostal arteries, making reimplantation inadvisable. The intercostal arteries in patients 7, 10, and 11 were oversewn with number 2 silk suture ligatures.

Perfusion data. A membrane oxygenator (Optima XP; Cobe Cardiovascular, Arvada, Colo) was used in all cases. The mean durations of cooling, circulatory arrest, low-flow hypothermic bypass, hypothermic ventricular fibrillation, rewarming, and cardiopulmonary bypass are shown in Table 2. The mean duration of circulatory arrest was $29 \pm 13$ minutes. A period of hypothermic low flow to the upper body after attachment of the aortic graft to the proximal aorta was used in 6 patients to minimize the interval of circulatory arrest. This was accomplished by using the second arterial line from the pump oxygenator attached to the $10-\mathrm{mm}$ side arm of the new aortic graft.

\section{Endovascular Operation}

Patients 6, 8, and 9 had intercostal patch aneurysms with anatomy favorable for endovascular stent graft repair (Figure 3). All had lumbar spinal 
TABLE 1. Patient characteristics

\begin{tabular}{|c|c|c|c|c|c|c|c|c|c|}
\hline $\begin{array}{c}\text { Patient } \\
\text { no. }\end{array}$ & $\begin{array}{r}\text { Age } \\
(y)\end{array}$ & Sex & $\begin{array}{c}\text { Marfan } \\
\text { syndrome }\end{array}$ & Previous operations & $\begin{array}{c}\text { Time to } \\
\text { patch } \\
\text { aneurysm }(y)\end{array}$ & $\begin{array}{c}\text { Intercostal } \\
\text { patch } \\
\text { diameter }(\mathbf{c m}) \\
\end{array}$ & $\begin{array}{l}\text { Reoperation } \\
\text { date }\end{array}$ & Repair & Postoperative \\
\hline 1 & 59 & Male & No & $\begin{array}{l}\text { Repair extent } 1 \text { TAAA } \\
\quad 1983\end{array}$ & 10.7 & 7.0 & 1994 & $\begin{array}{l}\text { Redo type I TAAA } \\
\text { repair with new } \\
\text { intercostal } \\
\text { patch (T7-T10) and } \\
\text { SMA/CA patch }\end{array}$ & $\begin{array}{l}\text { Recurrent intercostal } \\
\text { patch aneurysm, } 5.5 \\
\text { cm, } 2000 \\
\text { Death } 2001 \\
\quad \text { (unknown cause) }\end{array}$ \\
\hline 2 & 57 & Female & No & $\begin{array}{l}\text { Bentall, ascending } \\
\text { and arch repair } 1999 \\
\text { Repair extent I TAAA } \\
1997\end{array}$ & 0.1 & NA & 1997 & $\begin{array}{l}\text { Evacuation of left } \\
\text { hemothorax, } \\
\text { pledgeted } \\
\text { suture repair of false } \\
\text { aneurysm at suture } \\
\text { line of intercostal } \\
\text { patch }\end{array}$ & $\begin{array}{l}\text { Death } 2003 \text { (unknown } \\
\text { cause) }\end{array}$ \\
\hline 3 & 75 & Male & No & $\begin{array}{l}\text { Repair AAA } 1987 \\
\text { CABG } 1994 \\
\text { Repair arch and } \\
\text { proximal 2/3 DTA } \\
1994\end{array}$ & 3.6 & 7.0 & 1998 & $\begin{array}{l}\text { Resection of intercostal } \\
\text { patch and old aortic } \\
\text { graft, ligation } \\
\text { intercostal arteries } \\
\text { (T5-T8), interposition } \\
\text { graft }\end{array}$ & $\begin{array}{l}\text { Bronchopleural fistula } \\
\text { after surgical } \\
\text { intervention } 1998 \\
\text { Death } 2001 \\
\text { (fungal graft infection } \\
\text { with rupture) }\end{array}$ \\
\hline 4 & 42 & Female & Yes & $\begin{array}{l}\text { Bentall } 1990 \\
\text { Repair extent II TAAA } \\
1994 \\
\text { Repair MV and TV } \\
1997\end{array}$ & 6.1 & 8.0 & 2000 & $\begin{array}{l}\text { Resection of old graft, } \\
\text { new aortic } \\
\text { interposition } \\
\text { graft with side } \\
\text { branch to patent } \\
\text { intercostals (T7-T8) }\end{array}$ & $\begin{array}{l}\text { Death } 2008 \text { (cocaine, } \\
\text { cardiomyopathy) }\end{array}$ \\
\hline 5 & 52 & Female & Yes & $\begin{array}{l}\text { AVR } 1982 \\
\text { Redo AVR and arch } \\
\quad \text { repair } 1984 \\
\text { Repair extent II } \\
\quad \text { TAAA } 1995 \\
\text { Redo arch repair } 1997 \\
\text { Redo aortic arch } \\
\text { repair } 1997\end{array}$ & 8.7 & 7.0 & 2004 & $\begin{array}{l}\text { Redo type II TAAA } \\
\text { repair with new aortic } \\
\text { graft with side } \\
\text { branches to patent } \\
\text { intercostals (T10-12), } \\
\text { CA, SMA, RRA, and } \\
\text { LRA }\end{array}$ & $\begin{array}{l}\text { Death } 2008 \\
\text { (airway obstruction } \\
\text { after thyroidectomy) }\end{array}$ \\
\hline 6 & 57 & Female & No & $\begin{array}{l}\text { Repair ascending } \\
\text { aorta } 1997 \\
\text { Repair extent II } \\
\text { TAAA } 2005\end{array}$ & 0.7 & 6.4 & 2006 & $\begin{array}{l}\text { Two 31-mm Gore TAG } \\
\text { stent grafts }\end{array}$ & $\begin{array}{l}\text { Required left } \\
\text { thoracotomy and } \\
\text { Eloesser flap for } \\
\text { Candida species } \\
\text { empyema } 2007 \\
\text { Chronic } \\
\text { left empyema } \\
\text { Death } 2008 \\
\text { (unknown cause) }\end{array}$ \\
\hline 7 & 41 & Male & Yes & $\begin{array}{l}\text { Bentall and ascending } \\
\text { aorta } 1988 \\
\text { Repair extent I } \\
\text { TAAA } 2000\end{array}$ & 5.7 & 7.9 & 2006 & $\begin{array}{l}\text { Resection of intercostal } \\
\text { patch and old aortic } \\
\text { graft, ligation } \\
\text { of intercostal arteries } \\
\text { (T7-T10), new } \\
\text { interposition } \\
\text { aortic graft }\end{array}$ & $\begin{array}{c}\text { Alive } \\
\text { Follow-up to } 2007\end{array}$ \\
\hline 8 & 71 & Female & No & $\begin{array}{l}\text { Repair of ascending } \\
\text { aorta and arch } 2004 \\
\text { Repair extent I } \\
\text { TAAA } 2004\end{array}$ & 3.4 & 5.9 & 2007 & $\begin{array}{l}\text { Two 34-mm Gore TAG } \\
\text { stent grafts }\end{array}$ & $\begin{array}{c}\text { Alive } \\
\text { Follow-up to } 2008\end{array}$ \\
\hline
\end{tabular}


TABLE 1. Continued

\begin{tabular}{|c|c|c|c|c|c|c|c|c|c|}
\hline $\begin{array}{c}\text { Patient } \\
\text { no. }\end{array}$ & $\begin{array}{l}\text { Age } \\
(y)\end{array}$ & Sex & $\begin{array}{c}\text { Marfan } \\
\text { syndrome }\end{array}$ & Previous operations & $\begin{array}{c}\text { Time to } \\
\text { patch } \\
\text { aneurysm }(y)\end{array}$ & $\begin{array}{c}\text { Intercostal } \\
\text { patch } \\
\text { diameter }(\mathrm{cm}) \\
\end{array}$ & $\begin{array}{l}\text { Reoperation } \\
\text { date }\end{array}$ & Repair & Postoperative \\
\hline 9 & 41 & Female & No & $\begin{array}{l}\text { AVR, repair } \\
\text { ascending and arch } \\
1994 \\
\text { Repair extent I } \\
\text { TAAA } 1994\end{array}$ & 13.7 & 6.6 & 2008 & $\begin{array}{l}\text { 34-mm and } 28-\mathrm{mm} \\
\text { Gore TAG stent } \\
\text { grafts }\end{array}$ & $\begin{array}{c}\text { Intercostal artery } \\
\text { type II stent } \\
\text { endoleak } \\
\text { Alive } \\
\text { Follow-up to } 2008\end{array}$ \\
\hline 10 & 39 & Male & Yes & $\begin{array}{l}\text { Bentall } 1994 \\
\text { Repair of aortic arch } \\
\quad 1995 \\
\text { Repair extent II } \\
\text { TAAA } 2003 \\
\text { Redo aortic arch } 2004\end{array}$ & 4.7 & 6.3 & 2008 & $\begin{array}{l}\text { Resection of intercostal } \\
\text { patch and old aortic } \\
\text { graft, ligation } \\
\text { of intercostal } \\
\text { arteries (T7-T10), } \\
\text { new interposition } \\
\text { aortic graft }\end{array}$ & $\begin{array}{c}\text { Alive } \\
\text { Follow-up to } 2008\end{array}$ \\
\hline 11 & 39 & Male & Yes & $\begin{array}{l}\text { Bentall } 2001 \\
\text { Repair } \\
\quad \text { extent II TAAA } 2007\end{array}$ & 0.7 & 8.8 & 2008 & $\begin{array}{l}\text { Resection of intercostal } \\
\text { patch and old aortic } \\
\text { graft, ligation } \\
\text { of intercostal } \\
\text { arteries (T6-T8), } \\
\text { new interposition } \\
\text { aortic graft }\end{array}$ & $\begin{array}{c}\text { Alive } \\
\text { Follow-up to } 2008\end{array}$ \\
\hline
\end{tabular}

$T A A A$, Thoracoabdominal aortic aneurysm; $S M A$, superior mesenteric artery; $C A$, celiac artery; $A A A$, abdominal aortic aneurysm; $C A B G$, coronary artery bypass graft surgery; $D T A$, descending thoracic aortic aneurysm; $M V$, mitral valve; $T V$, tricuspid valve; $A V R$, aortic valve replacement; $R R A$, right renal artery; $L R A$, left renal artery.

drains placed. Our technique for endovascular stent graft repair is similar to that of previous reports. ${ }^{13,14}$ In brief, an OmniFlush catheter (Angiodynamics, Queensbury, NY) was passed percutaneously into the left common femoral artery, while a 22-gauge introducer sheath was placed over a Lunderquist wire (Cook Medical, Bloomington, Ind) through an exposed right common femoral artery. An aortogram was performed to evaluate the distal thoracic aorta and the celiac artery, and measurements were taken to determine the appropriate stent graft dimensions. A Gore TAG Thoracic Endograft (W. L. Gore and Associates, Inc, Flagstaff, Ariz) was then passed through the deployment sheath. The distal end was positioned just above the celiac axis. Puff injections through the angiogram catheter were performed to localize the axis and position the stent before deployment. After stent deployment, an angiogram determined that a second stent graft was required proximally for each patient to completely exclude the patch aneurysm. The stent grafts were anchored proximally and distally within the old aortic grafts. The proximal and distal landing zones were sealed with a Gore Tri-Lobe Balloon Catheter (W. L. Gore and Associates, Inc), and a final angiogram was completed to confirm the absence of an endoleak.

\section{Follow-up}

Patients were evaluated 1 month postoperatively and subsequently at 6month intervals with CT scans. Mean duration of follow-up was 3.0 years (range, 1 month-7.5 years).

\section{Statistical Analyses}

Data were analyzed with Intercooled Stata 9.2 software (StataCorp, College Station, Tex). Standard descriptive statistical analyses were used. Continuous data are presented as the mean \pm standard deviation. Categoric data are presented as proportions and were compared between groups by using a Fisher's exact test. Nonparametric estimates of freedom from all-cause death were determined by using the Kaplan-Meier method and are reported as the mean \pm standard error.

\section{RESULTS \\ Early Morbidity and Mortality}

Among the 8 patients who underwent open operations, there were no in-hospital deaths, reoperations for bleeding, strokes, or SCII. Patient 5 had a Candida species wound infection and transient postoperative renal dysfunction (peak creatinine value, $4.7 \mathrm{mg} / \mathrm{dL}$ ) but did not require dialysis. $\mathrm{Pa}$ tient 10 had pneumonia and sepsis and required a tracheostomy for prolonged respiratory support (17 days). He had Marfan syndrome and had undergone multiple previous operations. The mean duration of mechanical ventilatory support was $4.3 \pm 5.4$ days (median, 2.2 days). The duration of stay in the intensive care unit was $5.4 \pm 6.1$ days (median, 3.5 days), and hospital length of stay was $11.9 \pm 8.2$ days (median, 8.5 days).

No in-hospital deaths, reoperations for bleeding, strokes, or SCII occurred among the 3 patients who underwent endovascular repair. The hospital length of stay for these 3 patients was $3.7 \pm 0.6$ days.

\section{Late Morbidity and Mortality}

During the follow-up interval that extends to 7.5 years, there have been 6 late deaths occurring between 31 and 90 months postoperatively (Table 1). Five-year survival was $50 \% \pm 20 \%$. Patient 1 , who had a new intercostal patch fashioned at the time of his patch aneurysm repair, had a recurrent intercostal patch aneurysm, which measured $5.5 \mathrm{~cm}$ 6 years postoperatively. He died suddenly 1 year later. 


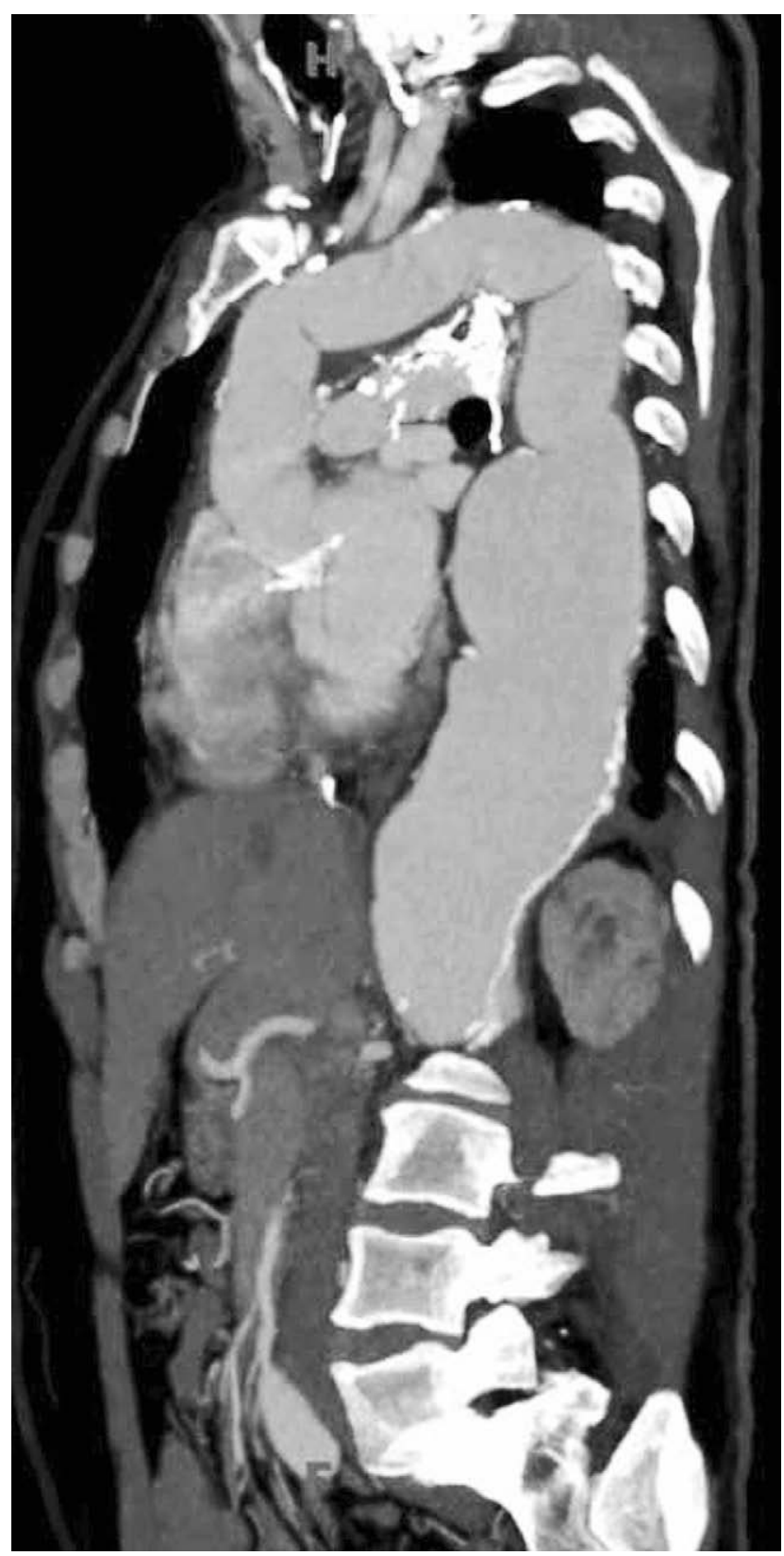

FIGURE 1. Computed tomographic image of a 39-year-old man with Marfan syndrome with a $6.3-\mathrm{cm}$ intercostal artery patch aneurysm 5 years after extent II TAAA repair. The patient underwent open surgical repair with resection of the intercostal patch, ligation of patent intercostal arteries, and insertion of an interposition aortic graft.

Patient 3 had a bronchopleural fistula 1 year after open aneurysm repair. He died 2 years later from chronic Aspergillus species aortic graft infection and aortic rupture into the left hemithorax. Patient 6 had a left-sided empyema (Candida species) 1 year after stent graft repair. She underwent surgical drainage of the empyema and creation of an Eloesser flap. After a prolonged course of antifungal treatment, she died 2 years after stent graft repair. One other patient died of unknown cause, and 2 patients died of non-graft-related

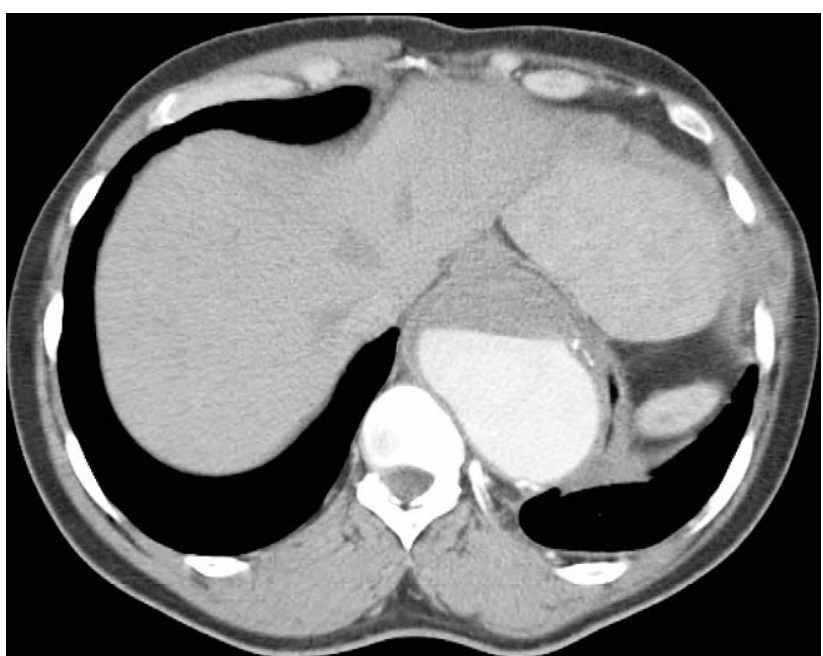

FIGURE 2. Computed tomographic image of a 39-year-old man with Marfan syndrome who underwent extent II TAAA repair 6 months earlier. Within the 8 -cm intercostal artery patch aneurysm, the patient had extensive thrombus adjacent to the celiac artery, necessitating an open surgical repair. The intercostal patch was resected, patent intercostal arteries were ligated, and a new interposition aortic graft was inserted.

causes (Table 1). The remaining patients have been free of symptoms and abnormal findings on serial CT examinations from 1 to 21 months postoperatively.

\section{DISCUSSION}

Although there is no consensus, the majority of centers with expertise in aortic surgery support the reimplantation of patent intercostal arteries below the T7-T8 level at the time of DTAA or TAAA repair to reduce the incidence of SCII. ${ }^{15}$ The intercostal arteries are believed to play a critical role in the maintenance of spinal cord perfusion and the prevention of perioperative SCII. ${ }^{1,16,17}$ However, this benefit must be balanced against the risk of leaving behind native aorta around the reimplanted vessels and the potential for aneurysmal expansion and rupture. ${ }^{3,4}$

Within a cohort of 155 patients followed prospectively after DTAA or TAAA repair with intercostal artery reimplantation, we observed that (1) the incidence of intercostal artery patch aneurysm development was $7.1 \%$ and most patients were asymptomatic, (2) patients with Marfan syndrome appeared to be at greater risk for the development of intercostal patch aneurysms, (3) the repair of intercostal patch aneurysms can be performed safely either with the use of hypothermic circulatory arrest and cardiopulmonary bypass or endovascular stent graft techniques in the presence of suitable landing zones, and (4) patients with intercostal patch aneurysms, often with a history of multiple previous cardiovascular operations, might face serious postoperative morbidity with the use of either repair technique.

To our knowledge, no study to date has documented the incidence of intercostal artery patch aneurysms after DTAA or 
TABLE 2. Cardiopulmonary perfusion data (8 patients)

\begin{tabular}{lcl}
\hline & Mean \pm SD & Range \\
\hline Time $(\min )$ & & \\
$\quad$ Cardiopulmonary bypass & $136.1 \pm 53.8$ & $75-241$ \\
Cooling & $35.6 \pm 12.8$ & $25-65$ \\
Circulatory arrest & $29.3 \pm 12.6$ & $16-48$ \\
Low-flow hypothermic bypass* & $37.8 \pm 15.8$ & $20-65$ \\
Hypothermic ventricular fibrillation & $84.1 \pm 25.4$ & $53-131$ \\
$\quad$ Rewarming & $70.8 \pm 34.5$ & $40-150$ \\
Temperature $\left({ }^{\circ} \mathrm{C}\right)$ & & \\
$\quad$ Lowest nasopharyngeal & $14.9 \pm 1.6$ & $13-18$ \\
Lowest bladder/rectal & $19.7 \pm 2.3$ & $17-21$ \\
\hline
\end{tabular}

$S D$, Standard deviation. *Six patients.

TAAA repair. However, 2 contemporary studies assessed the incidence of visceral artery patch aneurysms after TAAA repair. Tshomba and colleagues ${ }^{9}$ reviewed their experience within a cohort of 182 patients who underwent TAAA repair with visceral artery reimplantation by using the Crawford inclusion technique. At a mean interval of 6 years after TAAA repair, $6(3.3 \%)$ patients had visceral artery aneurysms $(>5$ $\mathrm{cm})$, and $1(0.5 \%)$ patient had a pseudoaneurysm. Similarly, Dardik and associates ${ }^{3}$ reviewed the Johns Hopkins experience of 107 patients who underwent TAAA aneurysm repair by using the Crawford inclusion technique and identified 8 (7.5\%) patients who had visceral patch aneurysms of greater than $4 \mathrm{~cm}$ in diameter during an average follow-up of 6.5 years after repair. The authors noted that patients with connective tissue disorders, such as Marfan syndrome, had a higher incidence of visceral patch aneurysms compared with patients with atherosclerotic disease $(17.6 \%$ vs $5.6 \%$, $P=.03)$. LeMaire and coworkers ${ }^{10}$ recently reported their experience with aortic operations in 300 patients with suspected or confirmed Marfan syndrome. After TAAA repair by their group, the authors reported a repair failure rate of $4 \%$ (8 patients), including the development of 6 recurrent aneurysms and 2 pseudoaneurysms at a mean of 7.2 years after the initial operation. The types of aneurysms were not specified. Our study has documented an incidence of intercostal artery patch aneurysms that approximates $7 \%$ after TAAA repair and further highlights the heightened risk of late complications among patients with connective tissue disease.

The importance of frequent radiographic surveillance after aortic surgical repair is evident in the fact that many patients with recurrent aneurysmal disease have few or no symptoms. After surgical intervention for acute aortic dissection or ascending aortic aneurysms, Mesana and colleagues $^{18}$ followed patients with magnetic resonance imaging and found a $15 \%$ incidence of thoracic aortic false aneurysm. Ten of the 12 patients who required reoperations were asymptomatic. Similarly, in a study from the Mayo Clinic, Villavicencio and associates ${ }^{19}$ reported on $57 \mathrm{pa}-$ tients with thoracic aorta false aneurysms, of whom $21 \%$ were asymptomatic and $65 \%$ were in functional class I or II. In the current study only 4 of 11 patients with intercostal patch aneurysms were symptomatic. This, we believe, further supports the need for continued surveillance. To document recurrent aneurysmal disease, we follow all of our patients after DTAA or TAAA repair with serial imaging every year, if possible, particularly those with connective tissue disorders or chronic aortic dissections. Given the risk of rupture, our policy is to operate on all patients with pseudoaneurysms along the intercostal patch suture line and on those with true aneurysms larger than $5.5 \mathrm{~cm}$ in size, symptoms, or radiographic evidence of rapid expansion.

The exact mechanism of intercostal artery aneurysm development is currently unknown. Chronic aortic dissection, a feature in 5 of our patients, might predispose patients to the development of intercostal aneurysms. At the time of aortic repair, by necessity, suture lines are placed in weakened aortic tissue, which carries with it the risk of subsequent pseudoaneurysm development. This can occur as early as 1 month postoperatively (patient 2). Connective tissue diseases, such as Marfan syndrome (present in 5 of our patients), also appear to be a risk factor for the formation of an intercostal patch aneurysm. Using either the Crawford or Carrel techniques to reimplant intercostal vessels leaves behind diseased and often fragile native aorta that is at risk for continued degeneration. It remains speculative whether graft replacement without preservation of intercostal
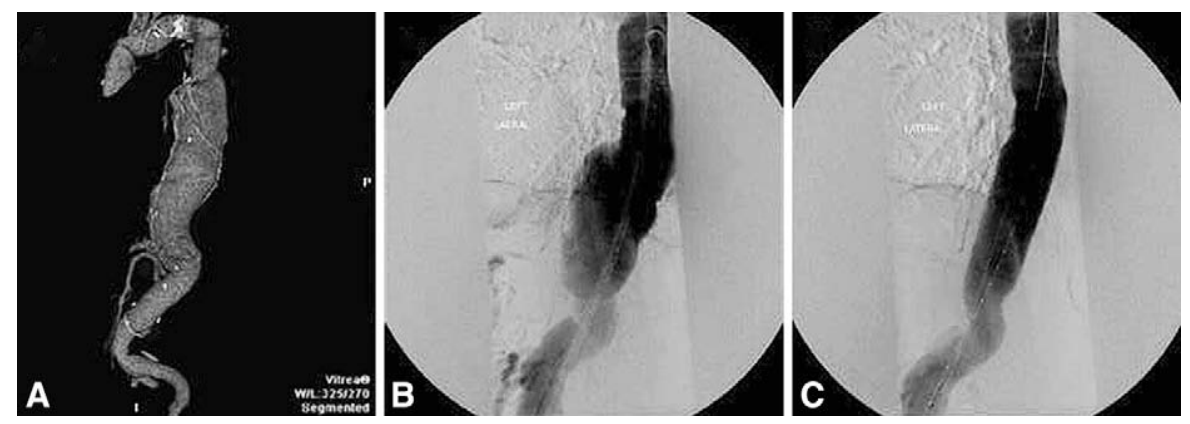

FIGURE 3. Computed tomographic image of a 71-year-old woman with a 5.9-cm intercostal artery patch aneurysm 3 years after extent I TAAA repair for a degenerative aneurysm (A). Intraoperative aortographic analysis confirmed the diagnosis (B). Placement of 2 endovascular stent grafts successfully excluded the patch aneurysm $(\mathrm{C})$. 
arteries, which could eliminate the possibility of a future patch aneurysm, is a suitable alternative. ${ }^{15} \mathrm{We}$ prefer to preserve the patency of all large patent intercostal arteries below the T5-T6 level, using as small a patch as technically feasible and recognizing the potential risk of late dilatation. In our view this approach is preferable, even in patients with connective tissue disorders, compared with the option of sacrificing these arteries. We believe intercostal artery reimplantation helps reduce the risk of SCII, a complication that would be especially devastating in a young patient with Marfan syndrome. Techniques of intercostal artery reimplantation using side-branch grafts anastomosed to the main aortic graft are alternative methods for managing intercostal arteries ${ }^{16,20}$; however, the long-term patency of such branch grafts is currently unknown.

Our experience illustrates that there are several surgical options for the management of intercostal artery aneurysms after DTAA or TAAA repair. Although we used intercostal patch reconstruction in our first case, we now avoid this technique given the risk of recurrent aneurysm formation. Our current preferred approach is endovascular stent graft repair, accompanied by drainage of cerebrospinal fluid. Although limited to 3 patients, we have not seen SCII with this technique, which is accompanied by drainage of cerebrospinal fluid. In patients who are not candidates for endovascular repair (ie, $<2 \mathrm{~cm}$ distal landing zone or extensive thrombus burden), we do not hesitate to perform open operations. We have not seen complications associated with the surgical ligation of small intercostal vessels at the time of reoperation in 4 of our patients. However, when we have encountered large patent lower intercostal arteries during patch aneurysm repair, we have used 8 - $\mathrm{mm}$ to 10 -mm side branch interposition grafts to preserve these vessels.

\section{Limitations}

This study is the first to describe the incidence of intercostal artery patch aneurysms and their management in a large consecutive series of patients. However, the results presented must be interpreted within the context of the study design. Observational in nature, this study involved the retrospective review of prospectively collected data in a referral-based tertiary care center. Because many patients are referred from afar, follow-up was not available for all patients. Every effort was made to obtain imaging surveillance at regular intervals, even if from a distance, and patient outcomes were documented through communication with patients, family members, or referring physicians. Nevertheless, it is possible that the incidence of intercostal artery patch aneurysms reported in the current study underestimates the true risk for the development of this complication. As noted above, 1 additional patient underwent open repair of an intercostal patch aneurysm at another institution 4 years after we performed a DTAA repair. Thus the incidence of intercostal artery patch aneurysms might be even higher.

\section{CONCLUSIONS}

In summary, we have documented that intercostal artery patch aneurysms are not infrequent complications after DTAA or TAAA repair, particularly in patients with connective tissue diseases. Careful follow-up with imaging is therefore critical. Intercostal patch aneurysms can be repaired safely with either open or endovascular techniques.

\section{References}

1. Safi HJ, Miller CC 3rd, Carr C, Iliopoulos DC, Dorsay DA, Baldwin JC. Importance of intercostal artery reattachment during thoracoabdominal aortic aneurysm repair. J Vasc Surg. 1998;27:58-68.

2. Crawford ES, Snyder DM, Cho GC, Roehm JO Jr. Progress in treatment of thoracoabdominal and abdominal aortic aneurysms involving celiac, superior mesenteric, and renal arteries. Ann Surg. 1978;188:404-22.

3. Dardik A, Perler BA, Roseborough GS, Williams GM. Aneurysmal expansion of the visceral patch after thoracoabdominal aortic replacement: an argument for limiting patch size? J Vasc Surg. 2001;34:405-10.

4. Dardik A, Krosnick T, Perler BA, Roseborough GS, Williams GM. Durability of thoracoabdominal aortic aneurysm repair in patients with connective tissue disorders. J Vasc Surg. 2002;36:696-703.

5. Kouchoukos NT, Masetti P, Rokkas CK, Murphy SF. Hypothermic cardiopulmonary bypass and circulatory arrest for operations on the descending thoracic and thoracoabdominal aorta. Ann Thorac Surg. 2002;74:S1885-98.

6. Kouchoukos NT, Mauney MC, Masetti P, Castner CF. Single-stage repair of extensive thoracic aortic aneurysms: experience with the arch-first technique and bilateral anterior thoracotomy. J Thorac Cardiovasc Surg. 2004;128:669-76.

7. Cambria RP, Clouse WD, Davison JK, Dunn PF, Corey M, Dorer D. Thoracoabdominal aneurysm repair: results with 337 operations performed over a 15-year interval. Ann Surg. 2002;236:471-9.

8. Coselli JS, LeMaire SA, Miller CC 3rd, Schmittling ZC, Koksoy C, Pagan J, et al. Mortality and paraplegia after thoracoabdominal aortic aneurysm repair: a risk factor analysis. Ann Thorac Surg. 2000;69:409-14.

9. Tshomba Y, Melissano G, Civilini E, Setacci F, Chiesa R. Fate of the visceral aortic patch after thoracoabdominal aortic repair. Eur JVasc Endovasc Surg. 2005;29:383-9.

10. LeMaire SA, Carter SA, Volguina IV, Laux AT, Milewicz DM, Borsato GW, et al. Spectrum of aortic operations in 300 patients with confirmed or suspected Marfan syndrome. Ann Thorac Surg. 2006;81:2063-78.

11. Kouchoukos NT, Masetti P, Murphy SF. Hypothermic cardiopulmonary bypass and circulatory arrest in the management of extensive thoracic and thoracoabdominal aortic aneurysms. Semin Thorac Cardiovasc Surg. 2003;15:333-9.

12. Coselli JS, Lemaire SA, Koksoy C, Schmittling ZC, Curling PE. Cerebrospinal fluid drainage reduces paraplegia after thoracoabdominal aortic aneurysm repair: results of a randomized clinical trial. J Vasc Surg. 2002;35:631-9.

13. Wheatley GH 3rd, Gurbuz AT, Rodriguez-Lopez JA, Ramaiah VG, Olsen D, Williams J, et al. Midterm outcome in 158 consecutive Gore TAG thoracic endoprostheses: single center experience. Ann Thorac Surg. 2006;81:1570-7.

14. Bavaria JE, Appoo JJ, Makaroun MS, Verter J, Yu ZF, Mitchell RS. Endovascular stent grafting versus open surgical repair of descending thoracic aortic aneurysms in low-risk patients: a multicenter comparative trial. J Thorac Cardiovasc Surg. 2007; 133:369-77.

15. Etz CD, Halstead JC, Spielvogel D, Shahani R, Lazala R, Homann TM, et al. Thoracic and thoracoabdominal aneurysm repair: is reimplantation of spinal cord arteries a waste of time? Ann Thorac Surg. 2006;82:1670-7.

16. Woo EY, McGarvey M, Jackson BM, Bavaria JE, Fairman RM, Pochettino A. Spinal cord ischemia may be reduced via a novel technique of intercostal artery revascularization during open thoracoabdominal aneurysm repair. J Vasc Surg. 2007;46:421-6.

17. Koshino T, Murakami G, Morishita K, Mawatari T, Abe T. Does the Adamkiewicz artery originate from the larger segmental arteries? J Thorac Cardiovasc Surg. 1999;117:898-905.

18. Mesana TG, Caus T, Gaubert J, Collart F, Ayari R, Bartoli J, et al. Late complications after prosthetic replacement of the ascending aorta: what did we learn from routine magnetic resonance imaging follow-up? Eur J Cardiothorac Surg. 2000;18:313-20.

19. Villavicencio MA, Orszulak TA, Sundt TM 3rd, Daly RC, Dearani JA, McGregor CG, et al. Thoracic aorta false aneurysm: what surgical strategy should be recommended? Ann Thorac Surg. 2006;82:81-9.

20. Toda K, Taniguchi K, Kainuma S, Yokota T. Novel technique for reimplantation of intercostal arteries using tailored patch graft. Eur J Cardiothorac Surg. 2008; 34:458-9. 